\title{
Resistance of Widows in Deepa Mehta's Water
}

\author{
Bimala Sharma \\ Associate Professor of English, \\ Nepal Sanskrit University, Nepal
}

\section{Introduction}

Deepa Mehta's Water (2005), set in 1938 explores the lives of widows in an ashram in Varanasi, India, narrates the story of bodies that enter into the machinery of power.

As Simone de Beauvoir's statement is 'one is not born, but rather becomes a woman' similarly widows also become or are produced by the society. The ashram works for the society as a production house which employs disciplinary frame to maintain or produce widows. The reason for this inclination is that the widowhood in Hinduism that Mehta critiques, requires knowledge of the system that is invisible which keeps the bodies in its grip to continue the widowhood as society demands. Mehta's film revolves around this theoretical framework with the aim of presenting how an individual suffocates under the pressure of disciplining regulations. This article, thus, aims to present the film as an examination of the ways in which the bodies (widows) are produced as are needed for the continuation of the society, how these bodies resist the forced manufacturing and how individuals attempt to change the power relations, resist and negotiate with disciplining forces and the limitations of this strategy. Water directed by Deepa Mehta is the primary data. Qualitative research method and feminism as theory is employed to meet the objective of this research article. Secondary data includes all the works related to this film and the theory of feminism. The Romanized version of the dialogues and their translations are done by researcher herself. Firstly, the article explains how widows are produced/ manufactured in which the process of production is explained which includes clothes/appearance, shelter and food then it focuses on how these bodies resist to the hegemonic disciplinary frames and finally breaks them which finally results in suicide and fleeing. Thus, the argument of this article will pivot around an institution within which Mehta successively situates her female characters: the widow ashram in Varanasi. Producing/ManufacturingWidows

The film begins with these quotations from The laws of Manu Chapter 5, Verse 156-161, Dharmashastras:

A widow should be long suffering until death, self restrained and chaste. A virtuous wife who remains chaste when her husband has died goes to heaven. A woman who is unfaithful to her husband is reborn in the womb of a jackal.(Mahadevan 171)

After the demise of her husband as the scriptures say that widows have three optionsmarry husband's younger brother, burn with the dead husband or lead a life of self-denial. Like the sati, ascetic widowhood is also symbolic of continued devotion to the dead husband's memory, and therefore a continuing symbol of martyrdom. 
Naming in Deepa Mehta's film has special significance.Major characters are Chuyia, Kalyani, Shakuntala, Narayan, Sadananda. Chuyia means a rat as she bites Madhumati and runs here and there her name is justified, Kalyani means one who works for welfare. Kalyani earns bread for all the widows in the ashramthat's why she has long uncut beautiful hair, her room is in attic upstairs, she is not asked to do any work, she is the privileged one. Shakuntala is the only one who is literate. Her self-confidence clearly is projected through her deep voice, dark looks and her actions. The ashram is in Dharmaghat which signifydharmic activities are only conducted but the act as prostitution, the language Madhumati speaks, the song Gulaboo sings all ridicules to what is expected and what actually happens in the ashram. All the widows in the ashram call didiwhich justify elder widows' function as agents of the institution to inject society's rules and regulation to turn youngers widow.

\section{Process of producing widow}

The film begins withChuyia eight years old married girl child chewing a stick of sugar cane sitting in a bullock cart accompanied by her sick old husband, her father and an old lady. Then it is shown that near a ghatChuyia's father wakes her up and asks whether she remembers her marriage and says "bitiyatumheyaadhyijiskesathtumaharabihahuwatha? Wo ab nadikibhet chad chukahyi. (baby do you remember the one with whom you were married to? He is now dead.)"She replies "nahi (No)" and he further informs "ab tum vidhwa ho gayi ho. (Now you have become a widow.)" Dharma as an institution is employed in makingof or producing the docile body.First, the psyche of Chuyiais attacked as she asks the innocent question Chuyia: "kabtak? (till when dad?)" This question mocks at how the child's mind is programmed.

The scene of the ghat is very powerful in showing how the body is disciplined on the name of dharma. Her old husbandis shown lying dead on the pier andChuyiais by his side. The old lady breaks red bangles worn by Chuyia with a stone. Water is poured on parted hair to wash off sindoor. Then Chuyia's long beautiful hair is chopped with a pair of scissors. The closeup scenes of choppingher hair is so vicious that it's a kind of physical and psychological torture. The sound and sight of moving scissors, sharpening of blade, falling of locks of chopped hair on her body, massaging of water on her head to soften hair, her innocent face, dark black eyes, her body wrapped in white cotton saree, all just expose the sufferings she is bearing in order to manufacture the docile body or product which dharma and society demands.

Then she is taken and deposited in the ashram in Varanasi populated by widows where "widows perform the motions of life according to the dictates of a code that decrees the accumulation of sat (truth) the lack of which in the first place has been the cause of the loss of the husband figure. Sat can be garnered only through the curtailment of worldly/bodily desires, such as those for dress, ornaments and rich food" (Chadha 93).As she peeps into this new world of ashram from behind the walls of the ashram she finds uniformity in the widows. All of them are wrapped in a white cotton saree their bodies are lean and thin except Madhumati's.Widows 
who are captivated in this ashram are there to produce them as perfect widows as Hinduism and the society demands and for that they need to undergo the procedure.

After having the view of the ashram, the conversation between the father and Chuyia goes like this Chuyia: "baba gharchale? (Dad let's go home?)." Father: "ab yahitumharagharhyi. (This is your home now)." Chuyia: "fir ammakaha? (Then where is mom?)" Chuyia is in pursuit of the former house with mom, dad, brother and sister. She is unknown of the fact that the demise of her husband kills her too and she becomes meaningless or useless to the home. After the death of the husband, she 'ceases' as a person and passes into a state of 'social death' which also signals her 'sexual death'... As a widow, she is reduced to a void, a zero" (Mukherjee 219). As she is turned into a zero now "the question rises about where to place her" (219). This is the reason she is deposited in theashram. This shows Chuyia is transferred from one institution a home with father and mother to this another institution the widow ashram.

As Chuyiaenters the ashramMadhumaticalls one of the widows "O Randi... (O strumpet...)" this is a great shock because this kind of foul language is not expected in such ashram.It is kind of resistance which has spilled because of agitation. Madhumati the matriarch of the ashram orders Kunti to leave Chuyia and asks Chuyia to come closer to her and explains her that now this is their and Mitthu's home and further she explains "shastrameinlikhahyiauratmardkiardhanginihotihyi jab wo zindahotahyi . . aur jab pati mar jatahyi ... to patnibhiadhi mar jatihyi to fir vidhwakodardkaisa" (in shastras it is written that woman is better half of a man till he is alive . . and when he dies . . she is also half dead so how can a widow feel the pain or get hurt) so this clarifies that as widows are half dead they should not feel the pain means their body and mind should practice bearing pain without any complain.

Then Chuyia says "humewidhawanahi banana hyi(I don't want to become a widow)" and as Madhumati says she will tie her hands and legs and throw her in Ganga she bites her foot and runs off and the whole environment turns out to be a playground since everyone runs to catch her and Madhumati gets agitated. Then Chuyia hides herself behind the door where Shakunatala is making turmeric paste. She asks Chuyia to sit in front of her showing her back then she applies the turmeric paste on her shaved head and asks her to sit in the sun which will heal the cuts, wounds and keep her head cool this clarifies how the body is processed to become a widow.

Further the conversation between Kalyani and Chuyia clarifies how dharma is injected into the psyche of a child. Chuyia: "kyaunkosunayidetahyi? (Can he hear?)" Kalyani: "unko sab sunayidetahyi. (Yes, he can hear everything.)"Chuyia: "kyakahaunhone? (What did he say?)" Kalyani: "tumyaha se jaldichalijaogi agar tumneJayshreekrishna ka jaapharroj 108 bar kiya. (He says you will go soon from here.If you chant Jayshreekrishna108 times a day." Chuyia: 
"108! mujhko to 10 tak hi ginanaaatahyi. (108! I know to count only up to ten.)"This shows Chuyia is illiterate and accepts what Kalyani teaches her. She starts chanting Jayshree Krishna even in the sleep so that one day God might accept her request and will take her home. While Kalyani and Chuyia go to Gangaghat to batheKaluthe puppy,at that time Kalyani says "juookesathsathpaapbhidhuljayenge (sins will also be washed off with the lice.)" So, bathing in Ganga for widows is not only about cleaning the body but purifying and cleansing the soul and body. As Chuyia runs after the puppy Kalyani runs after her while running she hits a married woman and she says in angst "kahabhagi ja rahi ho? (where are you running to?)" "tum to kuwariladkikitarahbhagi ja rahi ho. (You are running like an unmarried girl.)"This indicates widows are not allowed to run only unmarried girls can run.

\section{Clothes/Appearance}

Appearance is one of the major concerns. How a body of widow should appear according to Hinduism. Chuyia asks Narayan: "tumhepatahyi hum vidhawahyi? (Do you know I am a widow?)" only the first sight of Narayan can distinguish thatshe is a widow because "the body is not only a text of culture. It is . . a practical, direct locus of social control; it is a metaphor of culture" (Bordo13). As her whole body is wrapped in white cotton saree, bare footed, shaved head, weak, lean, thin,dark sad face, etc. all signify that she is a widow. She appears same as Hinduism has set the standards for a widow's appearance in India hence Narayan is able to know that she is a widow.

\section{Shelter}

Shelter is the next all widows live in the old tormented tattered ashram run on the money collected out of donations. Their shelter too is dark like their hearts because of the sadness of their lives. It is broken and old near Dharmaghat. The name Dharmaghatitself clarifies the purpose of the ashram but the movie mocks at it because the activities that are conducted inside goes against what the dharma says. All the widows except Madhumati sleep on a mat on floor in dark cold congested rooms without adequate ventilations.

\section{Food}

Food is one of the major ways of controlling the body. Buwa remembers her marriage "jab pandit mantra pad rahe the ammaekchantamarigaal par uske bad fere hone tak chu bhinahikiye hum (when the priest was chanting mantras my mother slapped me. After that till the whole ritual of marriage is over I didn't make a singlesound) . . . badabadagolgolrasgulla, garam garamgulaab jamun raaltapakrahithihumari(big big round roundrasgulla, hot hotgulaab jamun, my mouth was watering), besankeladdooasli ghee mein bane ...

sonekiashrafia ... (laddo made up of besan cooked in pure ghee ... gold coins, ... )"and then she asks Chuyia "tumharepaasladdoohyikya hum to sotejagte bas laddooke hi sapanedekhtehyi. (Do you have laddooday night I always dream of laddoo only?)" Chuyia goes to a nearby temple where she finds all the widows dancing and singing hymns which is the only entertainment or 
one can say is the way of keeping them engaged so that it is easy for them to live. At the gate of the temple these widows sit to beg alms Chuyia too sits there andgets few coins but she doesn't like to beg and gets irritated and goes off after getting few coins by a girland Chuyia vents her anger saying "doob mar (drown and die)" and goes and then one of the widows says "dhiredhireadat pad jayegi(gradually she'll be habituated)" this means it is also about habituating oneself into the system. Bordo argues that women use their bodies as a language of protest. They silently turn within themselves and search for ways to negotiate with the system so as to be able to practice their most natural human desire: freedom of expression. If verbal expression is frowned upon, their bodies are to be used, since it is what they are left with. Their bodies are their new texts, allowing them to communicate not through words but through actions (Bordo16). Hence stumping of Chuyia's feet reflect the same.

Chuyia buys laddoofor Buwa with the coins she gets as alms. While buying the laddooShopkeeper asks: "ye vidhwakabsejala bhuna khanelage? Bolkyachayie? (From when the widows started eating fried food? Say what you need?" and after having laddooBuwa dies as her desire of having laddoo is fulfilled. Buwa's desire to eat laddooexplains that at thame there used to be child marriages and they were not aware of what was going on they only remember their lust for delicious food.Kunti tastes each and every item before serving meal to Madhumati. The way she eats, gobbles and swallows the food clarifies her crave for thefood. All theother, except Madhuamti,are given very less food. While having food Buwa advises: "Chuyiajaldijaldi mat kha ekek daana chabachabake kha bhagwan jane aglakhanatumhekabmilega . . . (Chuyia don't eat fast. Chew each bite many times God knows when the next meal you will get.)"They were not certain about when they will get the next meal.

To achieve the body of widow it is necessary to process it in a perfect manner for that food is one the major elements. Widows in the ashram are deprived of sufficient, healthy, nutrient, fried, and fatty food this is the reason most of them are lean and thin only Madhumati and Chuyia are chubby. Madhumati being matriarch has control over everything so she can have whatever she likes and Chuyia is a child and the new entrant in the ashram.

Gulaboo the pimp supplies ganja (marijuana) to Madhumati and ferries prostitutes to the Seths in the town from the ashram. As she enters the ashram and sings: "sainyiabinagharsunaa ...

(the house is boring without husband)."This is ridiculous the norms of the ashramis broken because a pimp is allowed to sing such song andMadhumati the matron of the ashram uses ganja(marijuana) to control her sexual urge.

Narayan and Rabindra witness the scene of ferrying Kalyani to the next shore for prostitution and have conversation:"Rabindra: Wo dekhogayi(look she went). Narayan:kaungayi? (who went?)Rabindra: Vaishya kisi Seth se milneshayad mere babuji se. (prostitute to meet some Seth may be my dad)Narayan: Vaishya lagtihyi wo? koi vidhwahyibefkoof. (Does she look like a 
prostitute? Fool she is a widow) Rabindra: "Jantahun inn zameendaroko in vidhwaoonkeliye wo kyakehetehyiangrejimein "unnatural concern" wo hyiinkeliye. Inmein se shayad hi kisikanaaminhepata ho wo to badiwali, chchotiwali, motiwali. (I know these landlords have what it is called in English the 'unnatural concern' to these widows. Rarely any of them (landlords) know any of their (widows) names they just know the taller one, shorter one, fat one.)"

All this justifies how the body(Kalyani) is sent for the prostitution to run the institution called the ashram which is run on the basis of the donations given by these Seths and in return the ashram supplies them the widows as prostitutes. The body of Kalyani is manufactured for the purpose of prostitution that is why she is given more facilities than other widows in the ashram the extra saree, long hair, the room in the attic, she stays alone in a single room etc. This act is a criticism of how an institution the ashram which is the icon of dharma itself promotes prostitution which is against dharma. None can suspect that this kind of act can be conducted in such holy places.

\section{Resistance as shown in Water}

In the ashram, Mehta succeeds in projecting three major characters Chuyia, Kalyani and Shakuntala along with other characters who question institutions through their acts and dialogues. This film elaborates that some of the scenes, dialogues and actions in the film project resistance of the body to the hegemonic limitations. It also focuses on the changing social system of the India of the1930s, following a more radical way of resistance: suicide and fleeing away from the ashram. In the film, this argument of resistance is presented through Chuyia, Kalyani and Shakuntala.

At first, all of these characters follow the strategy of silence later the innocent questions raised by Chuyia, Kalyani's romance with Narayan and the counsel of Sadananda, a priest, who makes Shakuntala aware of her unjust and unholy situation prepared them to revolt against the hegemonic institution the ashram. If verbal expression is frowned upon, their bodies are to be used, since it is what they are left with. Their bodies are their new texts, allowing them to communicate not through words but through actions (Bordo 16). Hence stumping of Chuyia's feet after getting the alms reflects the same.

Shakuntala and Chuyia after taking bath in Ganga worship Sun and Chuyia asks "didikab khatam hogi? (Sister when will it be over?)" this means she is not concentrated on performing the ritual of prayer seriously rather she just wants to perform and finish. As Shakuntala asks her to sit properly Sadanandasuggests her saying "nayiayihyi . . daanto mat bachchihyi(she is new . . . don't scold her she is a kid)."'The new entrants take some time to learn the disciplinary things. Meanwhile Chuyia asks: "Didi aadmividhwa ka gharkahahyi? (sister where is the men widows' house?)" This shocks everyone and one of the widows says "Ram ramkaisaburashagunlekarayihyikyabolrahihyi.(oh God! what a bad omen what is she saying?)” Shakuntala gets into the river to fetch some water on the bank a marriage ceremony was going on and the priests says "bacha keparchayibhinapade (carefully even shadow is also not 
allowed)". Questioning and shadow of widow both are bad omen. "It is a self-effacing regime of fasting, purification and denial of bodily desires additionally loaded with the stigma of being inauspicious" (Chatterjee 81).

SadanandaandShakunatala's debate: Sadananda: "Ye agyanta hi humaradurbhagyahyi (this innocence is our curse). "Shakuntala Devi kitnesaaloon se tum ye kriya karrahi ho itnesaaloontaktumnetyagaurtapasyakihyi moksha kekitnepaaspahuchi ho tum? (Shakuntala Devi you have been performing this act since how many years how near to the salvation have you reached?) Shakuntala: "Agar moksha ka matlab vairagya hyi fir to nahi (if salvation means detachment then no)." Sadananda: "Fir bhikabhivishwas mat khona(then also don't give up the faith)." "The female psyche can be studied as the product of construction of cultural forces" (Showalter 16).This justifies how fake values are injected into the psyche of the widows and disciplined widow bodies are prepared according to the need of the society. Widows "had simply internalized society's norms"(Bloom 14).Kalyani suicides when she knew the Seth who enjoys her body is Narayan's father. Shakuntala after having discussion with Sadananda becomes clear that all the teachings of shastras are meant for continuing the society according to the interests of the powerful ones. When Shakunatala comes to know that Madhumati has send Chuyia for prostitution. The next morning, she carries Chuyia on her back all the way through the market to the railway station and hands her over to Narayan. The silence, the stumping of feet, verbal expressions, gestures, the use of foul languages, suicide, debate and finally the fleeing all are types of resistance.Chuyia at first is taken from one institution the home and deposited to the other the ashramand again she is taken from there and handed over to Narayan.The home, ashram and the final Narayan all are institutions which shape and produce the bodies.Chuyia's journey shows that the body is transferred from one manufacturing institution to the other.

\section{Conclusion}

Three major characters portrayed Chuyia, Kalyani and Shakuntala struggle to free themselves from the hegemony of patriarchy which wants them to become and live like a widow which they are not ready to accept as their fate. Mehta employs Chuyia's adventurous journey from a married girl child to a widow in ashram to show howbodies become widow or are produced/manufactured as widow. As mentioned clothes/appearance, food and shelter shape the body whereas shastrasshape the mind which is injected into the brains of widows by Sadananda and elder widows the so called didis. In early stage silence, verbal and physical expressions, gestures and postures, foul and sign languages, debates work as resistance later it turns to suicide and fleeing off the ashram. As a protagonist to question the system thatChuyia asks why there are no male widows and why only women are subjected to this regime?Chuyia's naivety results from the lack of a rigorous tutoring into the gender norms demanded by society. Shakuntala's 
unquestioned acceptance of the shastras, points to a deep-rooted indoctrination that compels her to accept the sufferings. Chuyia's questions,Kalyani and Narayan's romance, Kalyani's suicide and Chuyia'snear prostitution instigates Shakuntala to break the stereotype of the ideal upper caste Hindu woman/widow. Kalyani's suicide, Chuyia's fleeing off from the ashram and Shakutala's looking back at the audience in the end of the film all justify the resistance to the becoming of widow or the production/manufacture of widows.

\section{Works Cited}

Beauvoir, Simone De. The Second Sex. London: Vintage, 1997.

Bloom, Harold. (ed.), Alienation. New York: Infobase, 2009.

Bordo, Susan R. "The Body the Reproduction of Feminity: A Feminist Appropriation of

Foucault" Gender/Body/Knowledge: Feminist Reconstruction of Being and Knowing. Eds.

Alison M. Jaggar and Susan R. Bordo. New Brunswick: Rutgers University Press, 1989.

Chadha, Simran. "Marginalized by Domesticity: The (Un) Desirable Women of Deepa

Mehta's Triology- Fire, Earth and Water',Films, Literature \& Culture Deepa Mehta 's Elements Triology,Ed.Jasbir Jain, New Delhi: Rawat Publications, 2007, 85-99.

Chatterjee, Madhuri. “Women's Bodies, Women's Voices: Exploring Women's Sensuality in

Deepa Mehta's Trilogy", Films, Literature \& Culture Deepa Mehta's Elements Triology,Ed.Jasbir Jain, New Delhi: Rawat Publications, 2007, 75-84.

Mahadevan, Uma. "Readings, Misreadings and Fundamendalist Readings: Reflections on the Making of Deepa Mehta's Water"Films, Literature \& Culture Deepa Mehta 'sElementsTriology,Ed. Jasbir Jain, New Delhi: Rawat Publications, 2007, 168176.

Mehta, Deepa, director. Water. 2005.

Mukherjee, Tutun. "Deepa Mehta’s Film Water: Constructing the Dialectical Image” Films,

Literature \& Culture Deepa Mehta's Elements Triology,Ed.Jasbir Jain, New Delhi: Rawat Publications, 2007, 218-232.

Showalter, Elaine. "Feminist Criticism in the wilderness", Writing and Sexual Difference. Ed.

Elizabeth Abel, Sussex: The Harvester Press, 1982. 